\title{
Effect of microbial immunostimulants on WSSV infection percentage and the expression of immune-related genes in white shrimp (Litopenaeus vannamei)
}

Efecto de los inmunoestimulantes microbianos en el porcentaje de infección con WSSVy la expresión de genes relacionados con el sistema inmune del camarón blanco (Litopenaeus vannamei)

Efeito de imunoestimulantes microbianos sobre a porcentagem de infecção por WSSV e a expressão de genes relacionados ao sistema imune em camarões brancos (Litopenaeus vannamei)

Jesús A Fierro-Coronado ${ }^{1,2}$; Antonio Luna-González ${ }^{*}$; Carlos J Caceres-Martínez ${ }^{2}$; Píndaro Álvarez-Ruiz ${ }^{l}$; Ruth EscamillaMontes $^{l}$; Héctor A González-Ocampo ${ }^{l}$; Viridiana Peraza-Gómez ${ }^{3}$.

\footnotetext{
${ }^{1}$ Instituto Politécnico Nacional-Centro Interdisciplinario de Investigación para el Desarrollo Integral Regional, Unidad Sinaloa. Departamento de Acuacultura. Guasave, Sinaloa, Mexico.

${ }^{2}$ Universidad Autónoma de Baja California Sur, Carretera al Sur Km 5.5, C.P. 23080, La Paz, B.C.S., Mexico.

${ }^{3}$ Universidad Autónoma de Nayarit, Ciudad de la Cultura Amado Nervo. Tepic, Nayarit 62155, Mexico.
}

(Received: February 16, 2018; accepted: August 28, 2018)

To cite this article:

Fierro-Coronado JA, Luna-González A, Caceres-Martínez CJ, Álvarez-Ruiz P, Escamilla-Montes R, González-Ocampo HA, Peraza-Gómez V. Effect of microbial immunostimulants on WSSV infection percentage and the expression of immune-related genes in white shrimp (Litopenaeus vannamei). Rev Colomb Cienc Pecu 2019; 32(3):221-231.

DOI: https://doi.org/10.17533/udea.rccp.v32n3a07

\section{(cc) BY-NC-SA}

* Corresponding autor: Bulevar Juan de Dios Bátiz Paredes \# 250. Col. San Joachín. Guasave, Sinaloa, Mexico. E-mail: aluna@ipn.mx 


\begin{abstract}
Background: The white spot syndrome virus (WSSV) causes high mortalities in aquaculture. The use of immunostimulants increases animal resistance. Objective: To evaluate the WSSV infection percentage and the immunostimulant effect of lactic acid bacteria and yeast (MI= microbial immunostimulants) on WSSV infected Litopenaeus vannamei. Methods: A bioassay was performed for $33 \mathrm{~d}$, with treatments in triplicate. The MI was added to the feed at $8.5 \mathrm{mg} / \mathrm{kg}$ feed and offered to shrimp $(9.9 \pm 3.1 \mathrm{~g})$ daily, every 2 days, or every 3 days. Shrimp were infected with WSSV at 9 and 19 days. The expression of four immune system-related genes was studied using qRT-PCR. Results: No significant differences were observed in growth and survival among treatments. At the end of the bioassay, WSSV infection percentage (low viral load) decreased 8.3 and $25 \%$ in treatments III and IV as compared to the control group. Treatments with MI showed significant differences in the relative expression of $L v T o l l$, transglutaminase, and prophenoloxidase genes when MI was offered daily as compared to the control group. The MI did not regulate the expression of the superoxide dismutase gene. The WSSV infection percentage decreased when feed with MI was offered every $3 \mathrm{~d}$. Conclusion: The MI decrease WSSV infection percentage in $L$. vannamei infected with low viral load when it is offered every three days. The MI up-regulates LvToll, Tgase, and proPO genes when it is offered daily. Further research is needed regarding prophylactic treatment with microbial immunostimulants against WSSV in commercial shrimp farms.
\end{abstract}

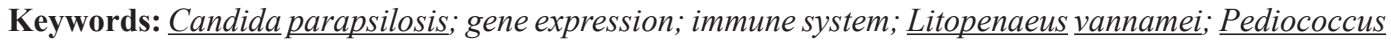
parvulus; shrimp; white shrimp.

\title{
Resumen
}

Antecedentes: El virus del síndrome de la mancha blanca (WSSV) ocasiona alta mortalidad en acuacultura. El empleo de inmunoestimulantes incrementa la resistencia de los animales. Objetivo: Evaluar el porcentaje de infección de WSSV y el efecto inmunoestimulante de bacterias ácido lácticas y levadura $(\mathrm{MI}=$ inmunoestimulantes microbianos) en Litopenaeus vannamei infectado con WSSV. Métodos: Se realizó un bioensayo durante 33 días con tratamientos por triplicado. Se agregó MI al alimento (8,5 $\mathrm{mg} / \mathrm{kg}$ de alimento), suministrandolo al camarón $(9,9 \pm 3,1 \mathrm{~g})$ diariamente, cada 2 , o cada 3 días. Los camarones se infectaron con WSSV a los 9 y 19 días. Se estudió la expresión de cuatro genes relacionados con el sistema inmune utilizando qRT-PCR. Resultados: No hubo diferencias significativas en el crecimiento y la sobrevivencia entre los tratamientos. Al final del bioensayo, el porcentaje de infección de WSSV (baja carga viral) disminuyó un 8,3 y un $25 \%$ en los tratamientos III y IV en comparación con el grupo control. Los tratamientos con MI mostraron diferencias significativas en la expresión relativa de los genes $L v T o l l$, transglutaminasa, y profenoloxidasa cuando se suministró MI diariamente en comparación con el grupo control. Los MI no regularon la expresión del gen de la superóxido dismutasa. El porcentaje de infección de WSSV disminuyó cuando el alimento con MI se aplicó cada 3 d. Conclusiones: Los MI disminuyen el porcentaje de infección de WSSV en L. vannamei infectado con baja carga viral cuando se aplican cada tres días. Además, los MI causan una sobre-expresión de los genes LvToll, Tgase y proPO cuando se administran diariamente. Se necesita más investigación sobre los inmunoestimulantes microbianos como tratamiento profiláctico contra WSSV en granjas comerciales de camarón.

Palabras clave: Camarón; camarón blanco; Candida parapsilosis; expresión de genes; Litopenaeus vannamei; Pediococcus parvulus; sistema inmune.

\section{Resumo}

Antecedentes: O vírus da mancha branca (WSSV) causa alta mortalidade na aqüicultura e o uso de imunoestimulantes aumenta a resistência em animais. Objetivo: Este trabalho avaliou a prevalência do WSSV e o efeito imunoestimulante de bactérias ácido lácticas e levadura (MI= inmunoestimulantes microbianos) em Litopenaeus vannamei infectado con WSSV. Métodos: Se realizou um bioensayo durante 33 dias com tratamientos por triplicado. Se agregou MI al alimento $(8,5 \mathrm{mg} / \mathrm{kg}$ feed) e se o fornecimento de camarão $(9,9 \pm 3,1 \mathrm{~g})$ diariamente, cada 2 e cada $3 \mathrm{~d}$. Los camarones foram infectados com WSSV a los 9 y $19 \mathrm{~d}$. Se estudió a expressão de quatro genes relacionados com o sistema imune, use qRT-PCR. Resultados: No hubo diferencias significativas no crescimento e na supervisão entre os tratamientos. Al final del bioensayo, a prevalência do WSSV diminuiu um 8.3 e não $25 \%$ nos tratamentos III e IV em comparação com o grupo de controle. Os tratamentos com MI mostraram diferenças significativas na expressão relativa dos genes. LvToll, transglutaminasa e prophenoloxidase quando se administraron em diários de MI em comparação com o controle 
de grupo. Los MI não regularam a expressão do genótipo da superóxido dismutasa. A prevalência do WSSV diminuiu quando o alimento com MI se aplicó cada 3 d. Conclusões: Los IM diminuir a prevalência de WSSV em L. vannamei infectado com baixa carga viral quando aplicável a cada três dias. Além disso, os IM causaram uma sobre-expressão dos genes LvToll, Tgase e proPO quando se administran diariamente. Há mais informações sobre imunoestimulantes microbianos como tratamento profiláctico contra WSSV en granjas comerciales de camarón.

Palavras-chave: Camarão; camarão branco; $\underline{\text { Candida parapsilosis; } \text {; expressão de genes; Litopenaeus }}$ vannamei; Pediococcus parvulus; sistema inmune.

\section{Introduction}

Worldwide aquaculture production exceeds 60 million tons per year and contributes with more than $40 \%$ to the production of aquatic organisms (FAO, 2016). However, diseases caused by viruses and bacteria are a primary concern for the development of this important activity (Lightner, 2011). White spot disease caused by white spot syndrome virus (WSSV) is a devastating disease for cultured penaeid shrimp (Joseph et al., 2015) and can not be treated with antibiotics as it happens with diseases caused by bacteria (Gatlin, 2002).

Immunostimulants are an alternative to antibiotics to prevent diseases in cultured animals (Cheng et al., 2014) since they increase animal resistance (Song and Hsieh, 1994). Regarding crustaceans, the immunostimulatory effect of molecules (sodium alginate, glucans, lipopolysaccharides, nucleotides, peptidoglycans, and chitosan) and of whole cells (yeasts and bacteria) have been studied (Luna González et al., 2013a; Ringø et al., 2012; Sajeevan et al., 2009a, b). Regarding yeast, Candida parapsilosis possesses immunostimulatory activity against WSSV and has supported high post-challenge WSSV survival (Wilsi et al., 2015).

Crustaceans, such as Litopenaeus vannamei, have two lines of defense. The first line is a physical barrier consisting of the cuticle, which prevents the entry of pathogens in the body. The second line is based on cellular and humoral effectors, which combine to combat pathogens, heal wounds and respond to biotic and abiotic stressors (Lemaitre and Hoffman, 2007). The cellular effectors in shrimp are hemocytes (granular, semigranular, and hyaline), which play a central role in phagocytosis, melanization, encapsulation, nodulation, cytotoxicity, apoptosis, interfering RNA, autophagy, interferon-type system, and coagulation of the hemolymph (Goncalves et al., 2014; Sun et al., 2010). The humoral effectors are the second line of defense and include agglutinins, profenoloxidase system, coagulation proteins, hydrolytic enzymes, antimicrobial peptides, nitric oxide, respiratory burst, and opsonization (Morales and Cuéllar et al., 2014; Cerenius and Söderhäll, 2004; Destoumieux et al., 2000; Jiravanichpaisal et al., 2006). The expression of immune-related genes in shrimp provides important information about the activation of the immune system and its modulation (Wang et al., 2007).

The aim of this work was to determine the effect of microbial immunostimulants on WSSV infection percentage and on the expression of immune-related genes in white shrimp (Litopenaeus vannamei), cultured in the laboratory and challenged with WSSV.

\section{Materials and methods}

\section{Ethical considerations}

This study complies with the Mexican Official Standard NOM-062-ZOO-1999, technical specifications for the production, care and use of laboratory animals.

\section{Animals and acclimatization}

Shrimp were obtained from Cuate Machado farm (Guasave, Sinaloa, Mexico) and transported to the CIIDIR-IPN facilities in a plastic tank $(250 \mathrm{~L})$ with sea water and constant aeration. Animals were maintained in an outside culture system in 120 L plastic tanks with 80 L filtered $(20 \mu \mathrm{m})$ sea water $(30 \%)$ and continuous aeration. Shrimp were fed with commercial feed (Purina ${ }^{\circledR}$, Ciudad de Mexico, Mexico, 35\% protein) twice daily at 09:00 and 16:00 h. 


\section{Preparation of viral inoculum and tissue paste}

A viral inoculum (stored at $-70^{\circ} \mathrm{C}$ ) with high viral load (single PCR) was used to infect shrimp to obtain fresh muscle and gills with WSSV. Muscle and gill tissues of moribund shrimp were analyzed by polymerase chain reaction (PCR) to confirm the presence of the virus. Half of the tissues obtained were stored at $-70{ }^{\circ} \mathrm{C}$ in Falcon tubes and the other half were placed in cold Eppendorf tubes to be macerated with a plastic pistil. After maceration, $1 \mathrm{~g}$ of tissue was placed in a $20 \mathrm{~mL}$ Falcon tube with $10 \mathrm{~mL}$ of cold saline solution $(2 \%)$. Individual samples were centrifuged at $17,000 \mathrm{~g}$, for $10 \mathrm{~min}$, at $4{ }^{\circ} \mathrm{C}$. The supernatants were filtered with syringe filters $(0.45$ and $0.25 \mu \mathrm{m})$, placed in cold Eppendorf tubes $(1.5 \mathrm{~mL})$ and stored at $-70^{\circ} \mathrm{C}$. The presence of WSSV in the inoculum was verified with simple ( $>1000$ copies of viral DNA, Lo et al., 1996a, b) and nested (10-50 copies of viral DNA, Lo et al., 1996a, b) PCR.

\section{Microbial immunostimulants (MI)}

Lactic acid bacteria (Pediococcus parvulus Lta2) and yeast (Candida parapsilosis Lt6) were isolated and characterized according to Apún Molina et al. (2009) and Luna González et al. (2013b), and tested in L. vannamei challenged with Vibrio sinaloensis according to Flores Miranda et al. (2011).

\section{Preparation of the experimental diet with powdered immunostimulants}

Microorganisms were grown and washed as described in Apún Molina et al. (2009). Cells were centrifuged at 5,000 $\mathrm{g}$ for $10 \mathrm{~min}$ and dried in an oven (Felisa, Zapopan, Jalisco, Mexico) at $74{ }^{\circ} \mathrm{C}$ for $4 \mathrm{~h}$. The dried cell pellet was ground in a mortar and then included in the commercial feed pellet (35\% protein) at $8.5 \mathrm{mg} / \mathrm{kg}$ feed $(50 \%$ P. parvulus and $50 \%$ C. parapsilosis). The amount of microbial immunostimulants (MI) was based on the work by Flores Miranda et al. (2011).

\section{Experimental design}

The bioassay was conducted for $33 \mathrm{~d}$ with shrimp weighing $9.9 \pm 3.1 \mathrm{~g}$. Ten shrimp were placed per tank. Treatments in triplicate were as follows: I) Control group, shrimp fed commercial feed + WSSV; II) shrimp fed commercial feed + MI ( $8.5 \mathrm{mg} / \mathrm{kg}$ feed $)$ daily + WSSV; III) shrimp fed commercial feed + MI ( $8.5 \mathrm{mg} / \mathrm{kg}$ feed) every $2 \mathrm{~d}+\mathrm{WSSV}$; IV) shrimp fed commercial feed + MI $(8.5 \mathrm{mg} / \mathrm{kg}$ feed $)$ every $3 \mathrm{~d}+$ WSSV. Shrimp were fed feed plus MI, except for the days (9 and 19) when animals were fed $250 \mathrm{mg}$ per tank of shrimp paste (muscle and gills) with a high WSSV load (single PCR, > 1000 viral particles). Healthy shrimp were fed on dead shrimp with WSSV to simulate a natural infection. Initially, animals were fed $5 \%$ of the mean body weight and adjusted thereafter according to the feeding response in each tank. Uneaten food and waste material were removed every $3 \mathrm{~d}$ before feeding, and $50 \%$ of the water was exchanged every $5 \mathrm{~d}$.

Physicochemical parameters like pH (HI 98127 $\mathrm{pH}$, Hanna Instruments, Woonsocket, RI, USA), salinity (refractometer W/ATC 300011, Sper Scientific, Scottsdale, AZ, USA), dissolved oxygen, and temperature (YSI model 55 oxygen meter, Yellow Spring Instruments, Yellow Springs, OH, USA) were monitored every $2 \mathrm{~d}$. At the beginning and the end of the bioassay, ammonium, nitrites, and nitrates were determined by the method of Strickland and Parsons (1972).

At the end of the bioassay, weigth and survival of shrimp were determined. Shrimp were analyzed separately for WSSV by single or nested PCR. In addition, hemolymph was extracted for the immune system analysis. During the bioassay, the physicochemical parameters (temperature, salinity, $\mathrm{pH}$, dissolved oxygen, ammonium, nitrites, and nitrates) were kept within the optimal intervals for shrimp culture according to Brock and Main (1994) and Boyd and Tuker (1988). Temperature ranged from $29.0 \pm 0.2$ to $29.5 \pm 0.3{ }^{\circ} \mathrm{C}$; salinity was between 31.5 \pm 0.6 and $32.2 \pm 0.6 \%$; disolved oxygen ranged from $5.6 \pm 0.06$ to $5.8 \pm 0.05 \mathrm{mg} / \mathrm{L} ; \mathrm{pH}$ was between 8.4 \pm 0.02 and $8.5 \pm 0.02$; ammonium ranged from 0.2 \pm 0.2 to $0.6 \pm 0.20 \mathrm{mg} / \mathrm{L}$; nitrite was between 0.012 \pm 0.001 and $0.014 \pm 0.002 \mathrm{mg} / \mathrm{L}$; and nitrate ranged from $0.05 \pm 0.05$ to $0.7 \pm 0.01 \mathrm{mg} / \mathrm{L}$.

\section{DNA extraction and WSSV infection percentage}

Genomic DNA was extracted from abdominal muscle and gill lamellas $(1: 1 \mathrm{w} / \mathrm{w})(100 \mathrm{mg})$ with 
DNAzol reagent $\left(\mathrm{MRC}^{\circledR}\right.$, Cincinnati, OH, USA) following manufacturer's instructions. Quantification and quality assessment of DNA were performed in a Pearl nanophotometer (Implen, Inc. Westlake Village, CA, USA). DNA was stored at $-20{ }^{\circ} \mathrm{C}$, until use. Twelve shrimp per treatment (four per tank) were sampled for WSSV infection percentage by single and nested PCR, using the primers WSSV out-1/WSSV out-2 (5'-ATC ATG GCT GCT TCA CAG AC-3' [forward]/5'-GGC TGG AGA GGA CAA GAC AT3' [reverse]) and WSSV in-1/WSSV in-2 (5'-TCT TCA TCA GAT GCT ACT GC-3' [forward] /5'-TAA CGC TAT CCA GTA TCA CG-3' [reverse]) (Kimura et al., 1996), which amplified genome fragments of 982 and 570 bp, respectively. Negative samples were analyzed by one-step PCR with an internal control that amplified a 298 bp segment of shrimp glyceraldehyde3-phosphate dehydrogenase (GAPDH) DNA, using the primers GAPDH298 and GAPDH298 (5'-TCA CCG TCT TCA ACG AGA TG-3' [forward]/5'-ACC CTC CAG CAT CTC GAA CT-3' [reverse]) (Tang and Lightner, 2001).

\section{Hemolymph extraction}

Two-hundred microliters of hemolymph were sampled from 3 intermolt shrimp per tank, 9 per treatment, from the pleopod base of the first abdominal segment with a sterile $1 \mathrm{~mL}$ siringe (27 G $\times 13 \mathrm{~mm}$ needle). Before hemolymph extraction, the siringe was loaded with $400 \mu \mathrm{L}$ of a precooled (4 $\left.{ }^{\circ} \mathrm{C}\right)$ solution (SIC-EDTA, Na2) $(450 \mathrm{mM} \mathrm{NaCl}, 10$ $\mathrm{mM} \mathrm{KCl}, 10 \mathrm{mM}$ Hepes, and $10 \mathrm{mM} \mathrm{EDTA} \mathrm{Na}_{2}, \mathrm{pH}$ 7.3) used as an anticoagulant (Vargas Albores et al., 1993). Hemolymph was placed in cold Eppendorf tubes $(1.5 \mathrm{~mL})$ and then centrifuged at $800 \mathrm{~g}$ for 6 min at $4{ }^{\circ} \mathrm{C}$. Plasma was discharged and the celular pellet was rinsed with $250 \mu \mathrm{L}$ of cold anticoagulant solution and resuspended in $300 \mu \mathrm{L}$ of Trizol reagent (Invitrogen, Carlsbad, CA, USA). Samples were stored at a $-70{ }^{\circ} \mathrm{C}$ until used.

\section{Total RNA isolation and cDNA synthesis}

Total RNA of hemocytes was extracted with Trizol reagent according to manufacturer's protocol. The RNA concentration and purity was analyzed in a Pearl nanophotometer. The RNA was treated with DNAse I (1 U/ $\mu \mathrm{L})$ (Sigma-Aldrich, St. Louis, MO, USA).
Reverse transcription was used to synthesize the first strand of cDNA using reverse transcriptase (Improm II, Promega, Madison, WI, USA) with the oligo dT20, $500 \mathrm{ng}$ of total RNA and an incubation temperature of $42{ }^{\circ} \mathrm{C}$ for $60 \mathrm{~min}$. The cDNA was diluted with $80 \mu \mathrm{L}$ of ultrapure water and stored at $-70{ }^{\circ} \mathrm{C}$ until analysis. Five microliters of this cDNA dilution was used as template in each qPCR reaction.

\section{Expression analysis of immune-related genes by $q P C R$}

The expression of four immune-related genes (toll receptor [LvToll], superoxide dismutase [SOD], prophenoloxidase [proPO], and transglutaminase [TGase]) in hemocytes (Table 1) of experimental shrimp was measured by quantitative real-time PCR using a CFX96 system and the CFX Manager version 3.0 (Bio-Rad Laboratories, Hercules, CA, USA). To find the best reference genes to normalize the expression of target genes, a stability analysis of ribosomal protein (40S-S24), actin ( $\beta$-actin), elongation factor 2 (EF2), and ribosomal protein (L21) genes (Table 1) was done with the algorithms GeNorm (Vandesompele et al., 2002) and NormFinder (Andersen et al., 2004), using the RefFinder web application (http://150.216.56.64/referencegene.php). The expression of target genes was normalized to the geometric mean of the most stable reference genes (EF1 $\alpha, \beta$-actin, and L21).

The expression of target and reference genes was determined using the primers found in Table 1. Amplifications were performed in triplicate in a 96-well plate with a final volume of $15 \mu \mathrm{L}$, containing $7.5 \mu \mathrm{L}$ of PCR Master Mix $2 x(1.5 \mu \mathrm{L}$ of $10 x$ reaction buffer, $0.75 \mu \mathrm{L}$ of $50 \mathrm{mM} \mathrm{MgCl}_{2}$, $0.3 \mu \mathrm{L}$ of $10 \mathrm{mM}$ dNTPs, $0.75 \mu \mathrm{L}$ of EvaGreen 20x [Biotium, Hayward, CA, USA], $0.1 \mu \mathrm{L}$ of $5 \mathrm{U} /$ $\mu \mathrm{L}$ Biolase DNA polymerase [Bioline ${ }^{\mathrm{TM}}$, Tauton, MA, USA], and $4.1 \mu \mathrm{L}$ ultrapure water), $0.5 \mu \mathrm{L}$ of each primer $(10 \mu \mathrm{M}$, Sigma-Aldrich, St. Louis, MO, USA), $3.5 \mu \mathrm{L}$ of ultrapure water, and $3 \mu \mathrm{L}$ of cDNA. The thermocycler conditions were as follows: $95^{\circ} \mathrm{C}$ for $3 \mathrm{~min}$ followed by 40 cycles at $95^{\circ} \mathrm{C}$ for $10 \mathrm{~s}, 60{ }^{\circ} \mathrm{C}$ for $15 \mathrm{~s}, 72{ }^{\circ} \mathrm{C}$ for $30 \mathrm{~s}$, and $79^{\circ} \mathrm{C}$ for $5 \mathrm{~s}$. After each reaction, a dissociation curve from 65 to $90{ }^{\circ} \mathrm{C}$ was recorded at increments of $0.5^{\circ} \mathrm{C}$, and examined for unique and specific products. 
Table 1. Specific primer sequences used for quantitative real time PCR.

\begin{tabular}{|c|c|c|c|}
\hline Genes & Primers & Sequence $\left(5^{\prime}-3^{\prime}\right)$ & References \\
\hline \multicolumn{4}{|l|}{ Immune-related } \\
\hline \multirow[t]{2}{*}{ Transglutaminase } & TGase-F & ССTCAGGATCTCCTTCACCA & Wang et al. (2010) \\
\hline & TGase-R & TTGGGAAAACCTTCATTTCG & \\
\hline \multirow[t]{2}{*}{ Superoxide dismutase } & SOD-F & ATCCACCACACAAAGCATCA & Wang et al. (2010) \\
\hline & SOD-R & AGCTCTCGTCAATGGCTTGT & \\
\hline \multirow[t]{2}{*}{ Toll receptor } & LvToll-F & ATGTGCGTGCGGATACATTA & Wang et al. (2010) \\
\hline & LvToll-R & GGGTGTTGGATGTCGAGAGT & \\
\hline \multirow[t]{2}{*}{ Prophenoloxidase } & proPO-F & GAGATCGCAAGGGAGAACTG & Wang et al. (2010) \\
\hline & proPO-R & CGTCAGTGAAGTCGAGACCA & \\
\hline \multicolumn{4}{|l|}{ Housekeeping } \\
\hline \multirow[t]{2}{*}{$40 S-S 24$} & Lv40S_S24-F & CAGGCCGATCAACTGTCC & Álvarez-Ruiz et al. (2015) \\
\hline & Lv40S_S24-R & CAATGAGAGCTTGCCTTTCC & \\
\hline \multirow[t]{2}{*}{ L21 } & L21Lv-F & GTTGACTTGAAGGGCAATG & Stephens et al. (2012) \\
\hline & L21Lv-R & CTTCTTGGCTTCGATTCTG & \\
\hline \multirow[t]{2}{*}{$E F 2$} & LvEf-F & CTGTGGTCTGGTTGGTGTTG & Álvarez-Ruiz et al. (2015) \\
\hline & LvEf-R & TCAGATGGGTTCTTGGGTTC & \\
\hline \multirow[t]{2}{*}{$\beta$-actin } & Actin-F & CCACGAGACCACCTACAAC & Wang et al. (2007) \\
\hline & Actin-R & AGCGAGGGCAGTGATTTC & \\
\hline
\end{tabular}

For each gene, efficiency (E) of the PCR reaction was determined by calculating a slope with five serial dilutions (dilution factor of 5 or 10) of a representative pool of $\mathrm{cDNA}[\mathrm{E}=10(-1 /$ slope $)-1]$. The expression of target genes was calculated by transforming the $\mathrm{Cq}$ values to relative quantities (RQ), using the equation $\left.R Q i j=E^{[(C q \text { mean })}-C q(i j)\right]$, where $E$ is the gene-specific efficiency, and $[(\mathrm{Cq}$ mean $)-\mathrm{Cq}(\mathrm{ij})]$ is the absolute difference for each $\mathrm{Cq}$ sample against the mean $\mathrm{Cq}$ in the dataset for each gene. Relative expression of each gene was calculated with the equation $\mathrm{RQ}^{\text {target}} /$ Geometric mean of $\mathrm{RQ}^{\text {reference genes }}$ (Vandesompele et al., 2002).

\section{Specific growth rate}

At the end of the bioassays, the specific growth rate (SGR) was determined using the following formula:

$$
\operatorname{SGR}(\% / \mathrm{d})=100\left(\operatorname{Ln~} \mathrm{W}_{\mathrm{t}}-\mathrm{Ln} \mathrm{W}_{0}\right) / \mathrm{t}
$$

Where $t$ is the culture period in days, $W_{0}$ is the natural logarithm of the weight of the shrimp at the beginning of the bioassay, and $\ln W t$ is the natural logarithm of the weight of the shrimp at day $t\left(W_{0}\right.$ and $W t$ are in grams).

\section{Statistical analysis}

One-way variance analysis (ANOVA) using the $F$ test was performed among treatments to examine the differences in growth performance and gene expression. Where significant ANOVA differences were found, a Tukey's HSD test was used to determine the nature of these differences at $(\mathrm{p}<0.05)$ (Zar, 1996).

\section{Results}

\section{Survival and growth}

Survival in the bioassay was $100 \%$ in all treatments (Table 2). Initial weight ranged from $0.72 \pm 0.01$ to 0.75 $\pm 0.02 \mathrm{~g}$. Final weight was between $4.04 \pm 0.22$ and 4.14 \pm 0.18 g. Regarding SGR, values ranged between 5.82 \pm 0.1 and $5.34 \pm 0.33 \% / \mathrm{d}$. No significant differences among treatments were found in growth (Table 2). 
Table 2. Effect of MI on the survival, growth, and WSSV infection percentage in $L$. vannamei cultured in the laboratory.

\begin{tabular}{lcccc}
\hline & \multicolumn{4}{c}{ Treatments } \\
Parameters & I & II & III & IV \\
\hline Survival (\%) & 100 & 100 & 100 & 100 \\
$\begin{array}{l}\text { Initial weight } \\
\text { (g) }\end{array}$ & $0.75 \pm 0.02$ & $0.74 \pm 0.01$ & $0.72 \pm 0.01$ & $0.74 \pm 0.01$ \\
$\begin{array}{l}\text { Final weight } \\
\text { (g) }\end{array}$ & $4.08 \pm 0.2$ & $4.04 \pm 0.22$ & $4.14 \pm 0.18$ & $4.12 \pm 0.18$ \\
$\begin{array}{l}\text { SGR (\%/d) } \\
\text { WSSV }\end{array}$ & $24.2 \pm 0.5$ & $24.3 \pm 0.9$ & $24.9 \pm 0.4$ & $24.5 \pm 0.5$ \\
infection (\%) & $91.6 \pm 0.3$ & $100 \pm 0.0$ & $83.3 \pm 0.6$ & $66.6 \pm 0.5$ \\
\hline
\end{tabular}

Treatments: I) Control group, shrimp fed commercial feed + WSSV; II) shrimp fed commercial feed + MI ( $8.5 \mathrm{mg} / \mathrm{kg}$ feed) daily + WSSV; III) shrimp fed commercial feed + MI ( $\mathrm{mg} / \mathrm{kg}$ feed) every $2 \mathrm{~d}+$ WSSV; IV) shrimp fed commercial feed + $\mathrm{Ml}$ (mg/kg feed) every $3 \mathrm{~d}+$ WSSV. Data are mean \pm SE.

\section{WSSV infection percentage}

Nested PCR analysis showed that $58.3 \%$ of the organisms from the stock were infected with WSSV (control without WSSV added). At the end of the bioassay, the WSSV infection percentage increased $8.4 \%$ in treatment II, where shrimp were fed daily with MI, as compared with control group. However, in treatments III and IV, where shrimp were fed every two and three days with the MI, WSSV infection percentage decreased by 8.3 and $25 \%$, respectively, as compared with control group (Table 2).

\section{Immune-related gene expression}

Figure 1 summarizes the results of gene expression in white shrimp fed MI. The additive modulated the expression of the LvToll, TGase, and proPO genes. In TGase and proPO, significant differences $(\mathrm{p}<0.05)$ were found among treatments I, II, and III, with higher gene expression in treatment II (shrimp fed daily with MI). In LvToll, significant differences ( $<<0.05)$ were found in treatment II as compared with treatments I, III, and IV. The mRNA expression of SOD gene remains unchanged $(\mathrm{p}>0.05)$.
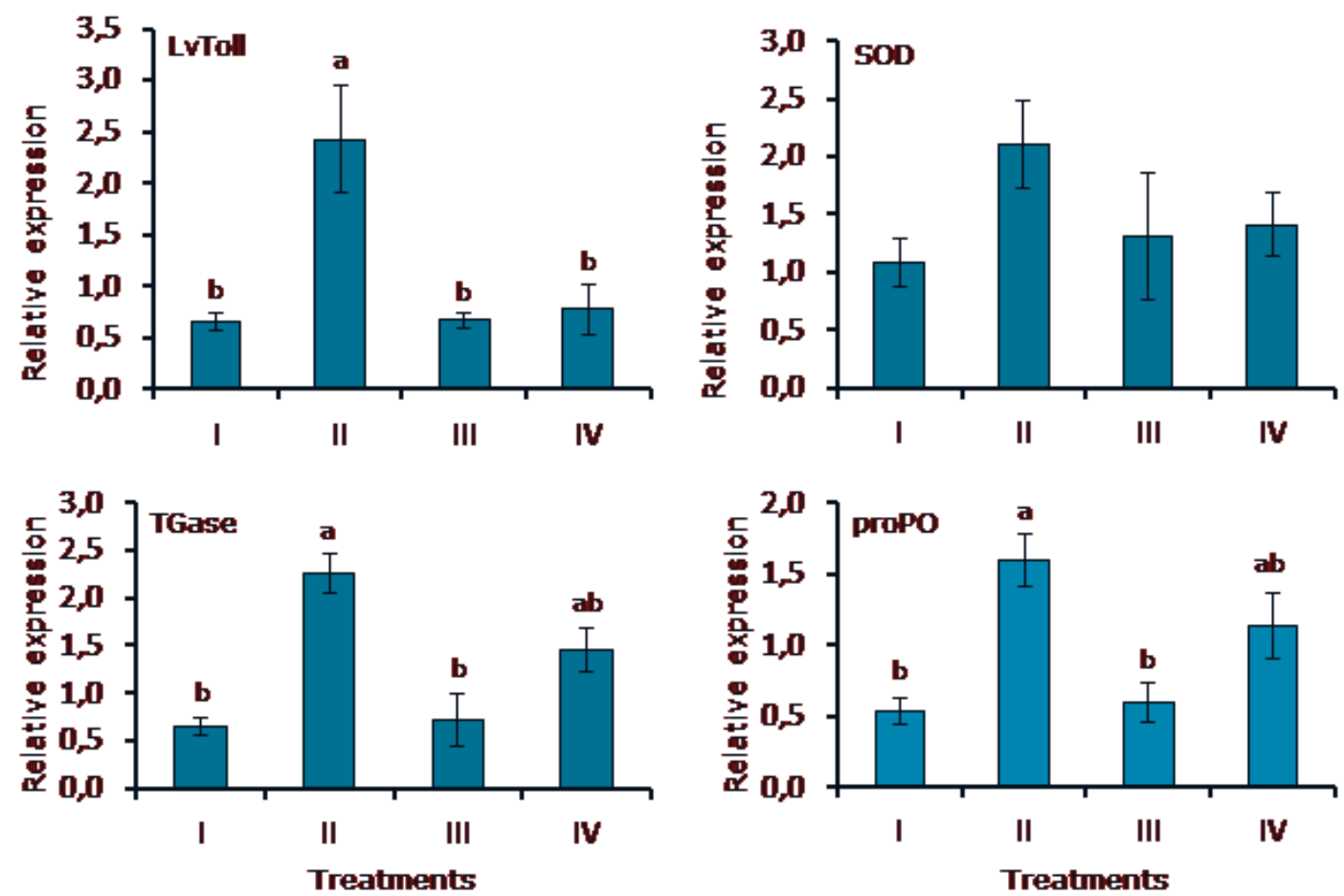

Figure 1. Immune-related gene expression in L. vannemei fed MI and challenged with WSSV. Treatments: I) Control group, shrimp fed commercial feed + WSSV; II) shrimp fed commercial feed + MI (mg/kg feed) daily + WSSV; III) shrimp fed commercial feed + MI (mg/kg feed) every $2 \mathrm{~d}+\mathrm{WSSV}$; IV) shrimp fed commercial feed + MI (mg/kg feed) every $3 \mathrm{~d}+\mathrm{WSSV}$. Relative expression of each gene was calculated with the equation RQtarget/Geometric mean of RQreference genes. Data are mean \pm SE. Different letters indicate significant differences. 


\section{Discussion}

The negative impact of white spot disease has been found in shrimp cultured worldwide. Because of the above, substances that strengthen the immune system of $L$. vannamei are now being investigated and to make it more resistant to diseases caused by pathogenic microorganisms; however, there is few scientific support for its function and dose/ frequency of application (Andrews et al., 2011; Sajeevan et al., 2009a). Therefore, in this work, the immunostimulating effect of a mixture of microorganisms (lactic acid bacteria and yeast) on WSSV challenged shrimp was evaluated.

The growth of organisms is influenced by environmental conditions such as temperature, $\mathrm{pH}$, salinity, and food availability (Oduleye, 1982). However, in the present work, growth was not negatively affected by the additives in the feed and because physicochemical parameters and water quality were kept within the optimal intervals for shrimp cultivation (Boyd and Tucker, 1988; Brock and Main, 1994). With respect to the survival of WSSV-infected shrimp, it was $100 \%$ in all treatments; results that agree with those reported by Partida Arangure et al. (2013), who worked with WSSVinfected shrimp using a mixture of lactic acid bacteria and bacilli in feed at a concentration of $1 \times 10^{5}$ $\mathrm{CFU} / \mathrm{g}$ feed, as well as inulin at 0.4 to $0.8 \mathrm{~g} / \mathrm{kg}$ feed. These findings corroborate that culture conditions in the laboratory are more stable that those found in the commercial shrimp farms.

The analysis showed that before the bioassay, $58.3 \%$ of the stock shrimp were infected with the virus (low viral load). Therefore, the infection in experimental shrimp was reinforced with shrimp paste. In this sense, it was observed that reinfection worked since $96.1 \%$ of the shrimp from the control group were WSSV positive. WSSV infection percentage decreased $8.3 \%$ in treatment III (shrimp fed MI every $2 \mathrm{~d}$ ) and $25 \%$ in treatment IV (shrimp fed MI every $3 \mathrm{~d}$ ) as compared with the control group (shrimp reinfected with WSSV). On the other hand, WSSV infection percentage in treatment II (shrimp fed MI daily) was increased $8.4 \%$ as compared with control group. The decrease in the WSSV infection percentage when the MI was administered discontinuously agree with the results obtained by Itami et al. (1998) in Penaeus monodon challenged with $V$. penaeicida and fed peptidoglycans $(0.2 \%$ of the diet) administered discontinuously. Similarly, Sajeevan et al. (2009a) reported a higher survival of Fenneropenaeus indicus challenged with WSSV orally and fed a glucan diet $(0.2 \%)$ every seven days. In the same way, Flores Miranda et al. (2011) found a higher survival of L. vannamei challenged with strains of $V$. sinaloensis and fed every three days with the same MI of this study.

In all living organisms, cells regulate their activities by modulating the expression of their genes. Gene expression is generally proportional to the number of copies of messenger RNA (mRNA) of a given gene. This is a crucial fact when it comes to identifying the presence of specific cellular products since the mRNA is translated into the ribosomes to form proteins. Thus, it is possible to obtain data concerning the production of biological elements if the expression of the genes of a cell is known (McPherson et al., 2008).

Toll receptors are highly conserved transmembrane proteins that are found in immune cells and recognize PMAPs (pathogen-associated molecular patterns) of microorganisms (lipopolysaccharides, peptidoglycans, betaglycans, flagellins, and others) (Akira and Hemmi, 2003). Transglutaminase (TGase) is involved in the polymerization of the coagulation protein in the plasma of decapod crustaceans (Liu et al., 2007) and is released as an immediate response of hemocytes to the presence of LPS and $\beta$-1,3-glucans (Montaño Pérez et al., 1999). Prophenoloxidase can be found in hemocytes as the inactive form of phenoloxidase and plays an important rol in the inate immune response because it allows the rapid response to bacteria and fungi (Amparyup et al., 2013). On the other hand, the $S O D$ enzyme converts the superoxide anion to hydrogen peroxide (Wang et al., 2010) and thus maintains the state of health and survival of organisms (Campa Córdova et al., 2005). In the present study, we found that the mRNA expression of LvToll, TGase, and proPO genes was significantly increased in treatment II, where the shrimp were fed daily with the MI as compared with control group and treatments III and IV, where shrimp were fed every two and three days with feed additives. However, in $S O D$ gene expression, the trend was similar, but there 
were no significant differences. It is posible that the increased gene expression of treatment II was due to the peptidoglycans and $\beta$-glucans of $P$. parvulus Lta 2 and $C$. parapsilosis since WSSV load in all treatments was low (10-50 viral particles). Moreover, it is known that the expression of LvToll, TGase, proPO, and $S O D$ genes can be suppressed or remain unchanged when shrimp are infected with WSSV (Ai et al., 2008; Arts et al., 2007; Wang et al., 2010; Yeh et al., 2009). Although genes were up-regulated in treatment II, the lower WSSV infection percentage occurred in treatment IV, where shrimp were fed every 3 days with MI. It is possible that continuous administration of immunostimulants causes immune fatigue in shrimp as reported by Bai et al. (2010) in $L$. vannamei fed $\beta$-glucan or glycyrrhizin. The above findings point out the importance of concentration and the frequency of application of immunostimulants in shrimp culture systems for effective protection against pathogens (Babu et al., 2013; Sajeevan et al., 2009a). Further research is needed about the effect of higher MI concentrations, added to the feed, in shrimp immune response and WSSV infection percentage.

In conclusion, despite the short period of time (14 days) from the last infection and the end of the bioassay, the tested MI decreased WSSV infection percentage in L. vannamei infected with low viral load when it was applied every three days. Also, results showed that MI up-regulates LvToll, TGase, and proPO genes, when it is given daily. Further research is needed about microbial immunostimulants as prophylactic treatment in commercial shrimp farms against WSSV.

\section{Acknowledgements}

The authors are grateful to Secretaria de Investigación y Posgrado del Instituto Politécnico Nacional (Mexico) for the financial support (20160629). Jesús A. Fierro-Coronado thanks CONACYT for the doctoral fellowship (237352).

\section{Conflicts of interest}

The authors declare they have no conflicts of interest with regard to the work presented in this report.

\section{References}

Ai HS, Huang YC, Li SD, Weng SP, Yu XQ, He JG. Characterization of a prophenoloxidase from hemocytes of the shrimp Litopenaeus vannamei that is down-regulated by white spot syndrome virus. Fish Shellfish Immunol 2008; 25: 28-39.

Akira S, Hemmi H. Recognition of pathogen-associated molecular pattern by TLR family. Immunol Lett 2003; 85: 85-95.

Píndaro Alvarez-Ruiz, Antonio Luna-González, Ruth EscamillaMontes, Claudio H. Mejía-Ruiz and Francisco J. MagallónBarajas, Raúl Llera-Herrera, Diego A. Galván-Alvarez. Longlasting effect against white spot syndrome virus in shrimp broodstock, Litopenaeus vannamei, by LvRab7 Silencing. J World Aquacult Soc 2015; 46(6): 571-582.

Andersen CL, Jensen JL, Orntoft TF. Normalization of realtime quantitative reverse transcription-PCR data: a modelbased variance estimation approach to identify genes suited for normalization, applied to bladder and colon cancer data sets. Cancer Res 2004; 64(15): 5245-5250.

Andrews SR, Sahu N.P, Pal AK, Mukherjee SC, Kumar S. Yeast extract, brewer's yeast and spirulina in diets for Labeo rohita fingerlings affect haemato-immunological responses and survival following Aeromonas hydrophila challenge. Res Vet Sci 2011; 91: 103-109.

Amparyup P, Charoensapsri W, Tassanakajon A. Prophenoloxidase system and its role in shrimp immune responses against major pathogens. Fish Shellfish Immunol 2013; 4: 990-1001.

Apún-Molina JP, Santamaría Miranda A, Luna González A, Martínez Díaz S F, Rojas Contreras M. Effect of potential probiotic bacteria on growth and survival of tilapia Oreochromis niloticus L., cultured in the laboratory under high density and suboptimumtemperature. Aquac Res 2009; 40: 887-894.

Arts JAJ, Cornelissen FHJ, Cijsouw T, Hermsen T, Savelkoul HFJ, Stet RJM. Molecular cloning and expression of a Toll receptor in the giant tiger shrimp, Penaeus monodon. Fish shellfish Immunol 2007; 23: 504-513.

Babu DT, Swapna PA, Simi PJ, Bright AR, Philip R. Marine yeast Candida aquaetextoris $\mathrm{S} 527$ as a potential immunostimulant in black tiger shrimp Penaeus monodon. J Invertebr Pathol 2013; 112: 243-252.

Bai N, Zhang W, Mai K, Wang X, Xu W. Ma H. Effects of discontinuous administration of $\beta$-glucan and glycyrrhizin on the growth and immunity of white shrimp Litopenaeus vannamei. Aquaculture 2010; 306: 218-224.

Boyd CE, Tucker CS. Pond Aquaculture Water Quality Management. Boston (EE.UU): Kluwer Academic Publishers; 1988.

Brock AJ, Main KL. A guide to the Common Problems and Disease of Cultured Penaeus vannamei. 1st Edn. The Oceanic Institute 1994; Honolulu-Hi, ISBN: 1-886608-00-8, 90-94.

Campa-Córdova AI, Hernández Saavedra NY, Aguirre Guzmán G, Ascencio F. Immunomodulatory response of superoxide dismutase in juvenile American white shrimp (Litopenaeus vannamei) exposed to immunostimulants. Cienc Mar 2005; 31(4): 661-669. 
Cerenius L, Söderhäll K. The prophenoloxidase-activating system in invertebrates. Immunol Rev 2004; 198; 116-126.

Cheng G, Hao H, Xie S, Wang X, Dai M, Huang L, Yuan Z. Antibiotic alternatives: the substitution of antibiotics in animal husbandry? Front Microbiol 2014; 5, 217. doi: 10.3389/ fmicb.2014.00217.

Destoumieux D, Muñoz M, Cosseau C, Rodríguez J, Bulet P. Comps M, Bachère E. Penaedins, antimicrobial peptides with chitin binding activity, are produced and stored in shrimp granulocytes and released after microbial challenge. J Cell Sci 2000; 113: 461-469.

FAO. The State of world fisheries and aquaculture. FAO Fisheries and Aquaculture Department. Food and Agriculture Organization of the United Nations. 2016. 230 pp.

Flores-Miranda MC, Luna González A, Campa Córdova AI, González Ocampo HA, Fierro Coronado JA, Partida Arangure BO. Microbial immunostimulants reduce mortality in whiteleg shrimp (Litopenaeus vannamei) challenged with Vibrio sinaloensis strains. Aquaculture 2011; 320: 51-55.

Gatlin DM III. Nutrition and fish health. In: Fish nutrition (ed. by J.E. Halver and R. W. Hardy): San Diego, (CA), USA Academic press; 2002: 671-702 p.

Goncalves P, Guertler C, Bachère E, de Souza CRB, Rosa RD, Perazzolo LM. Molecular signatures at imminent death: Hemocyte gene expression profiling of shrimp succumbing to viral and fungal infections. Dev Comp Immunol 2014; 42: 294-301.

Itami I, Asano M, Tokushige K, Kubono K, Nakagawa A, Takeno N, Nishimura H, Maeda M, Kondo M, Takahashi Y. Enhancement of disease resistance of kuruma shrimp, Penaeus japonicus, after oral administration of peptidoglycan derived from Bifidobacterium thermophilum. Aquaculture 1998; 164: 277-288.

Jiravanichpaisal P, Lee BL, Söderhäll K. Cell-mediated immunity in arthropods: Hematopoiesis, coagulation, melanization and opsonization. Immunobiology 2006; 11: 213-236.

Joseph TC, James R, Rajan LA, Surendran PK, Lalitha K. Occurrence of viral pathogens in Penaeus monodon post-larvae from aquaculture hatcheries. Data Brief 2015; 4: 170-176.

Kimura T, Yamano K, Nakano H, Momoyama K, Hiraoka M, Inouye K. Detection of penaeid-rod shaped DNA virus (PRDV) by PCR. Fish Pathol 1996; 31(2): 93-98.

Lemaitre B, Hoffmann J. The host defense of Drosophila melanogaster. Annu Rev Immunol 2007; 25: 697-743.

Lightner DV. Virus diseases of farmed shrimp in the Western Hemisphere (the Americas): A review J Invertebr Pathol 2011; 106: 110-130.

Liu YC, Li FH, Wang B, Dong B, Zhang QL, Luan W. A transglutaminase from Chinese shrimp (Fenneropenaeus chinensis), full-length cDNA cloning, tissue localization and expression profile after challenge. Fish Shellfish Immunol 2007; 22(5): 576-588.

Lo CF, Leu JH, Ho CH, Chen CH, Peng SE, Chen YT, Chou CM, Yeh P Y, Huang CJ, Chou HY, Wang CH, Kou GH. Detection of baculovirus associated with white spot syndrome (WSBV) in penaeid shrimps using polymerase chain reaction. Dis Aquat Org 1996a; 25: 133-141.

Lo CF, Ho CH, Peng SE, Chen CH, Hsu HC, Chiu YL, Chang CF, Liu K.F, Su MS, Wang CH, Kou GH. White spot syndrome baculovirus (WSBV) detected in cultured and captured shrimp, crabs and other arthropods. Dis Aquat Org 1996b; 27: 215-225.

Luna-González, A., Moreno-Herrera, J.T., Campa-Córdova, A.I., González-Ocampo, H.A, Fierro-Coronado, J.A., Álvarez-Ruiz, P., Bueno-Ibarra, M.A. Respuesta inmune y expresión de genes en el camarón blanco (Litopenaeus vannamei) inducida por inmunoestimulantes microbianos. Lat Am J Aquat Res 2013a; 41(5): 898-907.

Luna-González A, Quiñónez Zúñiga D, Fierro Coronado JA, González Ocampo HA, Campa Córdova AI, Flores Miranda MC, Peraza Gómez, V. Effect of Pediococcus parvulus and Candida parapsilosis on growth and survival of tilapia. Oreochromis niloticus and Oreochromis sp. Afr J Microb Res 2013b; 7(23): 2976-2982.

McPherson MJ, Hames BD, Taylor GR. PCR a Practical Aproach. First Editon edn. Oxford University Press Oxford; 2008.

Montaño-Pérez K, Reyes Izquierdo T, Vargas Albores F. El proceso de coagulación en camarones penaeidos. Ciencia 1999; 50: 23-28.

Morales V, Cuéllar A. Guía Técnica - Patología e Inmunología de Camarones Penaeidos. eds. Panamá (República de Panamá); 2014; p. 237-308.

Oduleye SO. Growth and growth regulation in the cichlids. Aquaculture 1982; 27: 301-306.

Partida-Arangure BO, Luna González A, Fierro Coronado JA, Flores Miranda MC, González Ocampo HA. Effect of inulin and probiotic bacteria on growth, survival, immune response, and prevalence of white spot syndrome virus (WSSV) in Litopenaeus vannamei cultured under laboratory conditions. Afr J Biotechnol 2013; 12(21): 3366-3375.

Ringø E, Olsen RE, GonzálezVecino JL, Wadsworth S, Song SK. Use of immunostimulants and nucleotides in aquaculture: a review. J Marine Sci. Res Development 2012; 1, 104. doi:10.4172/2155-9910.1000104.

Sajeevan TP, Rosamma P, Bright, Singh. I.S. Dose/frequency: a critical factor in the administration of glucan as immunostimulant to Indian white shrimp, Fenneropenaeus indicus. Aquaculture 2009a; 287: 248-252.

Sajeevan TP, Lowman DW, Williams DL, Selven S, Anas A, Rosamma, P. Marine yeast diet confers better protection than its cell wall component (1-3)- $\beta$-D-glucan as an immunostimulant in Fenneropenaeus indicus. Aquacult Res 2009b; 40: 1723-1730.

Song Y., Hsieh YT. Immunostimulation of tiger shrimp (Penaeus monodon) hemocytes for generation of microbiocidal substances: analysis of reactive oxygen species. Dev Comp Immunol 1994; 18: 201-209.

Stephens A, Rojo L, Araujo-Bernal S, García-Carreño F, MuhliaAlmazán A. Cathepsin B from the white shrimp Litopenaeus 
vannamei: cDNA sequence analysis, tissues-specific expression and biological activity. Comp Biochem Physiol B 2012; 161: $32-40$.

Strickland JDH, Parsons TR. A practical handbook of seawater analysis. Bullin Fisheries Research Board of Canada 1972; 167: 310.

Sun J, Wang A, Zhang T. Flow cytometric analysis of defense functions of hemocytes from the penaeid shrimp, Penaeus vannamei. J World Aquac Soc 2010; 41(1): 92-105.

Tang K, Lightner DV. Detection and quantification of infectious hypodermal and hematopoietic necrosis virus in penaeid shrimp by real-time PCR. Dis Aquat Organ 2001; 44: 79-85.

Vandesompele J, Preter KD, Pattyn F, Poppe B, Roy NV, Paepe AD, Speleman F. Accurate normalization of real-time quantitative RT-PCR data by geometric averaging of multiple internal control genes. Genome Biol 2002. 3(7), research0034.1

Vargas-Albores F, Guzmán M, Ochoa J. An anticoagulant solution for haemolymph collectionand prophenoloxidase studies of penaeid shrimp (Penaeus californiensis). Comp Biochem Physiol 1993; 106: 299-303.
Wang YC, Chang PS, Chen HY. Tissue expressions of nine genes important to immune defence of the Pacific white shrimp Litopenaeus vannamei. Fish Shellfish Immunol 2007; 23: 1161-1177.

Wang KCHC, Tseng CW, Lin HY, Chen IT, Chen YH, Chen YM, Chen YM, Chen TY, Yang HL. RNAi knock-down of the Litopenaeus vannamei Toll gene (LvToll) significantly increases mortality and reduces bacterial clearance after challenge with Vibrio harveyi. Dev Comp Immunol 2010; 34: 49-58.

Wilsi W, Douglas L, Swapna PA, Jayesh P, J, IS Bright, Rosamma. Immune gene expression profile of Penaeus monodon in response to marine yeast glucan application and white spot syndrome virus challenge. Fish Shellfish Immunol 2015; 43: 346-356.

Yeh SP, Chen YN, Hsieh SL, Cheng W, Liu CH. Immune response of white shrimp, Litopenaeus vannamei, after a concurrent infection with white spot syndrome virus and infectious hypodermal and hematopoietic necrosis virus. Fish Shellfish Immunol 2009; 26: 582-588.

Zar JH. Biostatistical analysis. 3rd ed. Englewood (Cliffs): Prentice-Hall; 1996. 662 pp. 